\title{
ФІНАНСОВО-ЕКОНОМІЧНА ДІЯЛЬНІСТЬ ДРУГОЇ УКРАЇНСЬКОЇ НАРОДНОЇ РЕСПУБЛІКИ
}

\author{
Ольга МАЛЮТА \\ Національний медичний університет імені О. О. Богомольця, \\ кафедра україністики, \\ просп. Перемоги 34, Київ, 03170, Україна \\ e-mail: maliutaov@meta.ua
}

У статті на основі аналізу архівних матеріялів та опублікованих документів Ради Народних Міністрів УНР, Міністерства фінансів УНР, Державного Центру УНР в екзилі автор доходить висновку, що урядовці другої Української Народної Республіки здійснювали самостійну фінансово-економічну політику.

Значний вплив на цю політику мали міжнародні фінансово-економічні договори доби Української Держави Павла Скоропадського з країнами Четвертного Союзу. Через відсутність власного Монетного двору УНР, за участі Німеччини, Польщі вдавалась до постійних емісій. 3 цими країнами, а також з Румунією, здійснювався торгово-економічний обмін. Таке співробітництво було на заваді, щоб налагодити співпрацю з країнами Антанти.

Директорія УНР постійно змінювала місця перебування, намагаючись повернутись до Києва, проводила низку соціяльно-економічних заходів. Упродовж існування Української Народної Республіки видано низку нормативно-правових актів, які мали налагодити соціяльно-економічне життя, наповнити державну скарбницю. В умовах воєнного стану, військових дій, відсутности надходжень до бюджету й контролю над значною частиною українських земель, постійних емісій, в Українській Народній Республіці розпочалась фінансова криза. Постійна підтримка Армії УНР, УГА, повстанського руху, вимагала значних витрат. Власну армію могла підтримувати тільки своя влада й власна держава. Перебування на інших землях призводило до роззброєння українських вояків.

Директорія УНР під впливом ухвал Паризької мирної конференції й захоплення українських земель іншими державами, змушена була утворити Державний центр УНР в екзилі та на довгі роки покинути рідну землю. У вигнанні провадила постійну боротьбу за відновлення втраченої Української національної держави. Результати боротьби за українську державність визначались незалежністю фінансово-економічного життя.

Ключові слова: гривня, Державний Центр УНР, Директорія УНР, екзил, емісія, міжнародна фінансово-економічна політика, Рада Республіки, українська державність.

Врегульована фінансова політика та економічний потенціял визначали результати українського національного державотворення у 1917-1921pp. Міжнародна політична ситуація, перерозподіл економічних сфер впливу й територіяльних надбань переможцями Першої світової війни впливали на фінансово-економічне життя в Українській Народній Республіці. Питання міжнародної фінансової діяльности Директорії УНР піднімались у праці П. Гай-Нижника' ${ }^{1}$. Соціяльно-економічне та

\footnotetext{
${ }^{1}$ Павло Гай-Нижник, Украӥнська дипломатія й міжнародна фінансова політика урядів Центральної Ради, Української Держави (Гетьманату) та Директорії УНР (1917-1922рр.). (К.: Дуліби, 2016), 532. 
фінансове життя в УНР не були предметом спеціяльної наукової студії, але стали доступними й зрозумілими в ракурсі дослідження Я. Бруські², спогадів тогочасних урядовців - I. Мазепи, I. Фещенка-Чопівського. Мета нашої статті: проаналізувати вплив міжнародної фінансово-економічної політики другої Української Народної Республіки у 1919-1921рp. на соціяльно-економічну ситуацію в державі й співпрацю 3 військово-політичними блоками.

В українській історіографії склався стереотип про пріоритетність у зовнішній політиці взаємин з Антантою, прагнення перетворити Великобританію, Францію, Сполучені Штати Америки у стратегічних союзників УНР. Підтримка і реалізація x боку гетьмана Павла Скоропадського Брестської мирної угоди, а, отже, налагодження стосунків з Четвертним союзом, згубно позначилось на співпраці 3 Антантою.

Одразу з приходом до влади Директорія УНР взялась впорядковувати фінансово-господарське життя. Дня 16 грудня 1918 р. по доповіді про фінансові ресурси УНР в урядових фінансових установах Києва В. Мазуренка, комісара при Міністерстві фінансів УНР, Рада комісарів УНР вжила заходів для успішного збору податків ${ }^{3}$. У грудні 1918 р. скасовано постанову про тимчасове обмеження права видавати кошти з приватних банків ${ }^{4}$.

У зовнішньоекономічній політиці Рада Народних Міністрів УНР продовжила співпрацю з Німеччиною. У грудні 1918 р. ухвалено постанову про купівлю у німців 1 млн. пудів кам'яного вугілля по 4 карб. 50 шагів за пуд-франко на ст. Голоби та 2 тис. кубів дров по визначеній на торгу ціні ${ }^{5}$. В умовах чергової війни Радянської Росії проти УНР, введення військ Антанти, особливих можливостей для поповнення державної скарбниці не існувало. Відтак 27 грудня 1918 р. Рада Народних Міністрів УНР вирішила провести додаткову емісію обсягом 3,5 млрд. крб. ${ }^{6}$. Проте свого Монетного двору Українська Народна Республіка не мала. Рада Народних Міністрів УНР лише у січні 1919 р. утворила окремий відділ, що мав займатись його створенням

Після укладеного Брестського мирного договору з Німеччиною, було підписано угоду від 14 квітня 1918 р. з Берлінською державною друкарнею на

${ }^{2}$ Jan Jacek Bruski, Petlurowcy: Centrum Państwowe Ukraińskiej Republiki Ludowej na wychodźstwie (1919-1924). (Kraków: ARCANA, 2004), 600.

${ }^{3}$ Журнал засідань Ради комісарів № 37 від 16.12.1918 р., Директорія, Рада Народних Міністрів Украӥнської Народної Республіки 1918-1920: Документи і матеріали, відп. ред. Владислав Верстюк: У 2 т., т. 1, (К.: Видавництво імені Олени Теліги, 2006), 93.

${ }^{4}$ Журнал засідань Ради комісарів № 40 від 20.12.1918 р., Директорія, Рада Народних Міністрів Украӥнської Народної Республіки 1918-1920, т. 1, 105.

${ }^{5}$ Журнал засідань Ради комісарів № 42 від 23.12.1918 р., Директорія, Рада Народних Міністрів Української Народної Республіки 1918-1920, т. 1, 109, 112.

${ }^{6}$ Журнал засідань Ради Народних Міністрів № 45 від 27.12.1918 р., Директорія, Рада Народних Міністрів Української Народної Республіки 1918-1920, т. 1, 122.

7 Журнал засідань Ради Народних Міністрів № 56 від 10.01.1919 р., Директорія, Рада Народних Міністрів Української Народної Республіки 1918 - 1920, т. 1, 170. 
ISSN 2078-6077. Наукові зошити історичного факультету Львівського університету. 2018-2019. Випуск 19-20. Proceedings of History Faculty of Lviv University. 2018-2019. Issue 19-20..

виготовлення паперових українських грошей ${ }^{8}$. Водночас угоду про виготовлення грошей уклали 3 власником одеської друкарні Е. Фесенком ${ }^{9}$ та Київською друкарнею ${ }^{10}$. На рахунок Одеської друкарні на поточні та операційні потреби 3 виготовлення грошей виділили 1 млн. крб. ${ }^{11}$ У Кам'янці-Подільському 3 переїздом туди уряду, почали друкувати грошові знаки номіналом $10,100,250$, 1000 крб. Цих знаків було замало для задоволення всіх потреб, оскільки українська валюта, як і валюти багатьох інших держав, швидко знецінювалась, кількість потрібних знаків зростала ${ }^{12}$. На момент приходу до влади Директорії УНР у державній друкарні Німеччини залишилось близько 10 млрд. грн. ${ }^{13}$. Рада Народних Міністрів УНР продовжила співпрацю з Німеччиною у питанні виготовлення грошей.

Дня 6 січня 1919 р. Директорія УНР прийняла “Закон про державну українську грошову одиницю” - гривню. Одна гривня містила 8,712 часток чистого золота, поділялась на сто шагів, дві гривні складали один карбованець. У загальноукраїнському обігу 16 січня 1919 р., у день оголошення Директорією УНР стану війни Радянській Росії, всі державні установи припинили приймати російські кредитові білети ${ }^{14}$. Урядовці намагались активізувати соціяльноекономічне життя, наповнити державну скарбницю, прийняти найважливіші закони. 8 січня 1919 р. Директорія УНР затвердила земельний закон, яким скасувала право приватної власности на землі, надаючи громадянам УНР лише право користування, право розпоряджатись надано верховній владі УНР. Домогосподарства могли мати в користуванні до 15 десятин землі ${ }^{15} .13$ січня 1919 р. прийняли закон про ліси, за яким всі громадські та приватні ліси без викупу стали власністю держави.

Рада Народних Міністрів УНР після укладання Акту злуки із ЗУНР намагалась забезпечити цілісне функціонування державно-правового механізму обох частин України та організувати спільне вирішення господарсько-економічних та фінансових питань. Практичне злиття двох частин України виявилось у підпорядкуванні економіки Галичини розпорядженням Директорії й відповідних міністерств УНР. Організація торговельного обміну між обома частинами України стосувалась спеціялізованих торговельних місій, що розміщувались в

\footnotetext{
${ }^{8}$ Марія Дмитрієнко, Віктор Ющенко та ін., Гроші в Украӥні: факти і документи. (К.: АРС "Україна", 1998), 26.

${ }^{9}$ Там же, 30.

${ }^{10}$ Там же, 31 .

${ }^{11}$ Центральний державний архів вищих органів влади та управління України (далі - ЦДАВО України), ф. 1509, оп.1, спр. 40, ч. II, арк. 191.

${ }^{12}$ Ісаак Мазепа, Украӥна в огні й бурі револючії 1917-1921. (К.; Темпора, 2003), 230.

${ }^{13}$ Там же, 229.

14 Закон про державну українську грошову одиницю від 6 січня 1919 р., у Директорія, Рада Народних Міністрів Украӥнської Народної Республіки. Листопад 1918 - листопад 1920. Документи і матеріали, упор, відп. ред. Владислав Верстюк: У 2 т., т. 2. (К.: Видавництво імені Олени Теліги, 2006), 412-413.
} 
окремих містах Галичини. Головним товаром експорту Західної области до УНР у 1919 р. були нафтові вироби та сіль, за них з Великої України отримували збіжжя та цукор. Влада УНР відповідно до своєї інтеграційної політики завозила товари за цінами, чинними у Наддніпрянщині. Галичина зберігала митні кордони в односторонньому порядку, що значно підвищувало вартість експортованої продукції. Через це Рада Народних Міністрів УНР була змушена забезпечувати державу румунською та кавказькою нафтою ${ }^{16}$.

Фінансування військ УНР на теренах Західної області, де домінувала австрійська крона, здійснювалось в українській національній валюті. У лютому 1919 р. австрійські крони постановою голови Директорії УНР В. Винниченка визнали чинними платіжними знаками, їх оцінили у 80 шагів або 40 коп. за одну. Українська національна рада 4 квітня 1919 р. ухвалила закон про введення в обіг гривень і карбованців в Західній області УНР (1 гривня $=1$ кроні, 1 крб. $=2$ грн. або 2 кронам). Фінансові видатки УНР на допомогу Західній області, утримання армії, шляхів, дипломатичних місій за кордоном, галицького уряду й інших установ становили 10,1 млн. американських доларів у 1919 р., більш як чверть видатків УНР ${ }^{17}$. Української валюти потребували для розрахунків 3 арміями союзників ${ }^{18}$, оскільки використання військовиками цих армій власних грошей, створювало проблеми у взаємовідносинах з населенням.

Рада Народних Міністрів УНР затвердила 24 січня 1919 р., який підготувала попередня влада, проєкт закону про Державний бюджет УНР на 1919 р. Загальна сума надходжень бюджету передбачалась у сумі 3 млрд. 179 млн. крб., видатків 5 млрд. 346 млн. крб. Дефіцит бюджету становив 2 млрд. 97 млн. крб. ${ }^{19}$. Дефіцит бюджету Італії у 1919 р. становив 27,2 млрд. лір, Німеччини - 265 млрд. марок ${ }^{20}$. Проте, для молодої Української Народної Республіки “бюджетна діра" була значною, iї треба було якось латати. Ситуація впорядкування фінансового життя держави утруднювалась тим, що того ж 24 січня 1919 р. прийнято “Закон про оголошення військового стану та стану облоги на Україні”, яким введено військовий стан на всій території УНР.

Порушений товарообмін між УНР та іншими державами, містом та селом, повністю розвалена податкова система, бюджет, що 1919 р. не поповнювався, свідчили про фінансову кризу. Оцінюючи реальну ситуацію того часу, український історик В. Верстюк писав, що фінансова криза підривала українську державність істотніше, ніж невдачі на фронті. Грошей бракувало, щб утримувати армію,

\footnotetext{
15 Земельний закон від 8 січня 1919 р., у Директорія, Рада Народних Міністрів Украӥнської Народної Республіки. Листопад 1918 - листопад 1920, т. 2., 413-417.

${ }^{16}$ Jan Bruski, Petlurowcy: Centrum Państwowe Ukraińskiej Republiki Ludowej na wychodźstwie (1919-1924), 77.

${ }^{17}$ Марія Дмитрієнко, Віктор Ющенко та ін., Гроші в Украӥні: факти і документи, 45

18 Там же, 43

${ }^{19}$ Там же, 35

${ }^{20}$ ЦДАВО України, ф. 1509, оп. 1, спр. 209, арк. 123-123 зв.
} 
ISSN 2078-6077. Наукові зошити історичного факультету Львівського університету. 2018-2019. Випуск 19-20. Proceedings of History Faculty of Lviv University. 2018-2019. Issue 19-20..

державно-адміністративний апарат, системи освіти, охорони здоров'я. Основним джерелом фінансових ресурсів для уряду стала грошова емісія. ${ }^{21}$. Через видатки на армію Рада Народних Міністрів УНР постановою від 24 лютого 1919 р. збільшила випуск грошових знаків Державної скарбниці до 8 млрд. грн., постановою від 23 липня 1919 р. ще на 2 млрд. грн. ${ }^{22}$. Загальна сума емісії становила 10 млрд. крб. ${ }^{23} .27$ жовтня 1919 р. Рада Народних Міністрів дозволила міністрові фінансів додаткову емісію 5 млрд. грн. ${ }^{24}$. Емісії призвели до знецінення українських грошей. В Україні перебувало 10-12 млрд. крб. грошових знаків. Оцінка витрат на військо та хлібну компанію становила до 1 млрд. крб., додатково планувалось надрукувати грошові знаки на 11 млрд. крб. ${ }^{25}$. Попри зусилля у створенні податкової системи, проводити земельну реформу, налагоджувати роботи промислових підприємств, ситуація в країні залишалась катастрофічною ${ }^{26}$. Попередні емісії за дуже приблизними підрахунками Державного Банку за період від грудня 1917 р. до 1 червня 1920 р. разом із забракованими грошовими знаками склали 13,95 млрд. грн. ${ }^{27}$. Загальна сума емісій від грудня 1917 до січня 1921 р. становила понад 17 млрд. грн., 3 них у грошовий обіг у період від 29 січня 1919 р. до 1 січня 1921 р. випущено 9,7 млрд. грн. Розмір граничної емісії планувалось довести до 35 млрд. грн. ${ }^{28}$.

Основою забезпечити грошову одиницю в Україні були зерно і цукор. Через відсутність у селян золота ще у 1917 р., за першої УНР, забезпечували належний грошовий фонд запасами цукру і борошна. Їх було достатньо через державну монополію, котру запровадив ще царський уряд ${ }^{29}$. У 1918-1920 pр. українські гроші забезпечувались майном. Місцеві, відомчі, приватні грошові знаки містили текст про забезпеченість емісій майном міста, спілки, підприємства. Ідея випуску перших паперових грошей грунтувалась на забезпеченні їх майном УНР й державною монополією на цукор і борошно ${ }^{30}$. Ціни на цукор постійно регулювала держава. В січні 1919 р. Рада Народних Міністрів УНР у розпорядження міністра фінансів асигнувала 22 млн. крб. для закупівлі цукру у німців, при цьому

${ }^{21}$ Владислав Верстюк. “Передмова”, у Директорія, Рада Народних Міністрів Української Народної Республіки 1918-1920: Документи і матеріали, відп. ред. Владислав Верстюк: У 2 т., т. $1,21$.

22 Журнал засідань Ради Народних Міністрів № 167 від 23.07.1919 р., Директорія, Рада Народних Міністрів Української Народної Республіки 1918-1920, т. 1, 429

${ }^{23}$ Марія Дмитрієнко, Віктор Ющенко та ін., Гроші в Україні: факти і документи, 46.

${ }^{24}$ Журнал засідань Ради Народних Міністрів № 232 від 27.10.1919 р., Директорія, Рада Народних Міністрів Украӥнської Народної Республіки 1918-1920, т. 1, 564.

${ }^{25}$ Марія Дмитрієнко, Віктор Ющенко та ін., Гроші в Украӥні: факти і документи, 45.

${ }^{26}$ Верстюк Владислав. Передмова, у Директорія, Рада Народних Міністрів Української Народної Республіки 1918-1920: Документи і матеріали, т. 1, 22.

${ }^{27}$ Марія Дмитрієнко, Віктор Ющенко та ін., Гроші в Украӥні: факти і документи, 50.

${ }^{28}$ Там же, 52.

${ }^{29}$ Там же, 21.

${ }^{30}$ Iсторія грошей і банківництва, ред. проф. Сергія Реверчука (К.: Атіка, 2004), 15. 
збільшено граничну ціну на цукор ${ }^{31}$. Водночас Українська Народна Республіка підтримувала міждержавний торговельно-економічний обмін. На прохання болгарського посла I. Шишманова вирішили 15-20 тис. тонн жита передати Болгарії ${ }^{32}$. Міністерство народного господарства УНР влітку 1919 р. уклало угоду з румунськими банками про постачання в Україну різних товарів в обмін на наші товари, цукор, збіжжя. Практично одночасно уклали договір з Польщею, умови, якого до кінця 1919 р. виконувала лише УНР (вивезла до Польщі близько 20 тис. пудів цукру) ${ }^{33}$.

Рада Народних Міністрів УНР 4 лютого 1919 р. прийняла “ЗЗакон про видачу довгострокових позичок центральним кооперативним установам на фінансування української промисловости". Міністрові фінансів УНР відповідно до закону передали 286 млн. грн. на виплату позик центральним українським кооперативним інституціям для фінансування української кооперативної промисловости ${ }^{34}$. У лютому 1919 р. уряд УНР виділив 500 млн. грн. для закупівлі за кордоном речей першої необхідности через центральні кооперативні організації ${ }^{35}$, 3 цих коштів 3 жовтня 1919 р. ухвалили фінансувати закупівлі кооперативними установами збіжжя та інших товарів на внутрішньому й зовнішньому ринку ${ }^{36}$.

Директорія УНР 9 березня 1919 р. ухвалила “Закон про хлібну повинність”, згідно з яким господарства, що мали три і більше десятин землі з урожаю 1919 р. мали здати державі від 20 фунтів до 325 пудів хліба зерном (при кількості 29 десятин). Приймались пшениця, жито, просо, гречка, чечевиця, квасоля, горох, ячмінь, овес, олійне насіння. Зерно мало бути сухе та якісне. Решту хліба, за наявности отриманої після здавання норми посвідки, господарствам дозволяли продати зерно за вищими цінами. У власників, що відмовлялись здавати зерно, проводили втричі більшу реквізицію за заниженими вдвічі цінами ${ }^{37}$. Господарства, які мали в користуванні понад дві десятини землі, зобов'язували передати державі за фіксованими цінами 3 двох - трьох десятин - 3 пуди зернових продуктів, 3 10-11 десятин - 47 пудів, 3 14-15 десятин - 93 пуди. У місцевостях, де не провели земельну реформу, господарства з земельними наділами понад 15 десятин,

\footnotetext{
${ }_{31}^{11}$ Журнал засідань Ради Народних Міністрів № 65 від 23.01.1919 р., Директорія, Рада Народних Міністрів Украӥнської Народної Республіки 1918-1920: Документи і матеріали, т. 1, 209.

32 Журнал засідань Ради Народних Міністрів № 46 від 29.12.1918 р., Директорія, Рада Народних Міністрів Української Народної Республіки 1918-1920: Документи і матеріали, т. 1, 125.

${ }^{33}$ Ісаак Мазепа, Украӥна в огні й бурі революиії 1917-1921, 299.

34 Закон про видачу довгострокових позичок центральним кооперативним установам на фінансування української промисловості від 4 лютого 1919 р., Директорія, Рада Народних Міністрів Украӥнської Народної Республіки 1918-1920: Документи і матеріали, т. 2, 470-471.

${ }^{35}$ Журнал засідань Ради Народних Міністрів № 77 від 08.02.1919 р., Директорія, Рада Народних Міністрів Украӥнської Народної Республіки 1918-1920: Документи і матеріали, т. 1, 247.

${ }^{36}$ Журнал засідань Ради Народних Міністрів №216 від 03.10.1919 р Директорія, Рада Народних Міністрів Української Народної Республіки 1918-1920: Документи і матеріали, т. 1, 534.

37 “Закон про хлібну повинність від 9 березня 1919 р.," Вістник Державних Законів УНР, Вип. 19. (1919): 26 червня.
} 
ISSN 2078-6077. Наукові зошити історичного факультету Львівського університету. 2018-2019. Випуск 19-20. Proceedings of History Faculty of Lviv University. 2018-2019. Issue 19-20..

зобов'язували здати урядові з перших 15 десятин 93 пуди зернових, а з решти весь урожай. Половину зернових обов'язково передавали житом та пшеницею, решту - іншими зерновими. Землі, що перебували в тимчасовому користуванні безземельного та малоземельного населення, та площі буряково-цукрових плантацій звільнялись від повинности ${ }^{38}$. Яку кількість зерна вдалося зібрати державі в умовах постійних переїздів державної влади та підвищення обороноздатности невідомо. Проте самостійно забезпечувати себе мусила навіть армія.

Прем'єр-міністр УНР Ісаак Мазепа помилково вважав, що Румунія, яка претендувала на Бессарабію та Північну Буковину, ставилась із симпатією до Української самостійної держави. Після переходу на територію Румунії Запорізького корпусу та інших військових частин у квітні 1919 р. їх роззброїли, та, попри дипломатичне втручання, зброю так і не повернули, побоюючись реакції держав Антанти й, вважаючи ймовірним захоплення зброї більшовиками, оскільки не вірили, що український уряд втримається в Україні ${ }^{39}$.

У літні місяці 1919 р. Українська Галицька Армія, що, порівняно 3 наддніпрянською, мала організованіші запільні частини, краще від Армії УНР заготовляла різні харчові запаси на зиму. Основою для підтримки нормального стану УГА були збіжжя (зібрано в жнива близько 800 тис. пудів), цукор (роздобули у цукроварнях Поділля), сіль (30 вагонів військової здобичі, за яку виміняли черевики та одяг). Відчувався брак набоїв та амуніції. На території України переважно всі військові заводи містились на Лівобережжі, постачати армію через торгівлю з іншими державами не було змоги ${ }^{40}$. В Армії УНР швидко поширювалась епідемія плямистого тифу, бракувало чобіт та теплого одягу, санітарного майна та ліків ${ }^{41}$. Потреби УГА у 1919 р. зросли більш, ніж вдвічі, тому грошових знаків, що друкував український уряд, додатково до ввезених 3 Німеччини, не вистачало. Організувати друк грошових знаків у потрібних кількостях власними технічними засобами і на своїй території у час загального занепаду та постійних евакуацій було неможливо. 310 млрд. грн. до Кам'янця у липні-жовтні 1919 р. вивезено 1,5 млрд., прибуло близько 1 млрд., решта згоріла або була розграбована при перевозі ${ }^{42}$. Влітку 1919 р. поширилось фальшування та несанкціонований випуск Добровольчою армією А. Денікіна та більшовиками грошових знаків на захопленому обладнанні. В Одесі добровольці надрукували значну кількість грошових знаків номіналом 50 крб., відомих як “денікінські лопатки”. Фальшиві “шалівки” номіналом 40 та 50 крб. виготовляли у Білій Церкві, Житомирі, Бердичеві ${ }^{43}$.

\footnotetext{
38 “Хлібна повинність з урожаю 1919 р.,” Україна, 16 серпня, 1919.

${ }^{39}$ Ісаак Мазепа, Україна в огні й бурі революиїі 1917-1921, 298-299.

${ }^{40}$ Ісаак Мазепа, Украӥна в огні й бурі революиії 1917-1921, 228-229.

${ }^{41}$ Там же, 298.

${ }^{42}$ Там же, 229.

${ }^{43}$ Марія Дмитрієнко, Віктор Ющенко та ін., Гроші в Украӥні: факти і документи, 47.
} 
ISSN 2078-6077. Наукові зошити історичного факультету Львівського університету. 2018-2019. Випуск 19-20. Proceedings of History Faculty of Lviv University. 2018-2019. Issue 19-20.

Окрім емісій грошових знаків, одним із основних прибуткових джерел мав стати продаж продуктів виробництва 3 націоналізованих промислових підприємств; цукру і спирту. Головні запаси цих продуктів мали прийти лише наприкінці року, їх збут був важким через загальне зубожіння населення й неможливість вивозу за кордон. В умовах постійних евакуацій та зміни територій, неможливо було чітко організувати збір податків ${ }^{44} .21$ червня 1919 р. Міністрові фінансів УНР надали право підвищувати ціни на цукор. Встановлені фіксовані ціни на цукор: на пісок -520 грн. за пуд, на рафінад - 600 грн. за пуд ${ }^{45}$. За кілька місяців втричі подорожчав цукор. Відтак 9 жовтня 1919 р. Директорія УНР установила новий граничний розмір скарбової продажної ціни на цукор-пісок 1600 грн. за пуд і на рафінад - 1800 грн. за пуд ${ }^{46}$, граничну продажну ціну скарбового спирту - у 100 грн. градус ${ }^{47}$. Дня 17 жовтня 1919 р. Рада Народних Міністрів УНР дозволила Міністрові фінансів у надзвичайних випадках продавати спирт та цукор по вільних ринкових цінах ${ }^{48}$.

Відтак 17 серпня 1919 р. Рада Народних Міністрів УНР ввела закон про трудову повинність громадян УНР. Закон поширювався на осіб від 18 до 45 років. Від загальної трудової повинности звільнялись духовні особи, військові, урядовці, співробітники оборонних підприємств, хлібороби, домогосподарки, вагітні жінки, матері дітей до 15 років, учні на час занять, каліки ${ }^{49}$.

В умовах фінансової кризи Директорія УНР, щоб утримати незалежність України, витрачала значні кошти на військо та розвідку. У серпні 1919 p. Директорія УНР затвердила постанову про асигнування в розпорядження військового міністра 6 млн. грн. на видатки із вивчення служби чужоземних військ й організацію зв'язку із закордоном ${ }^{50}$.

Дня 4 вересня 1919 р. Рада Народних Міністрів УНР ухвалила не оподатковувати підприємства 3 прибутком до 3 тис. грн., вирішила збільшити податок 3 міського нерухомого майна ${ }^{51}$. Та під впливом денікінської навали,

\footnotetext{
${ }^{44}$ Ісаак Мазепа, Україна в огні й бурі революиії 1917-1921, 230.

45 Журнал засідань Ради Народних Міністрів № 142 від 21.06.1919 р., Директорія, Рада Народних Міністрів Украӥнської Народної Республіки 1918 - 1920: Документи і матеріали, т. 1, 373-374.

46 “Збільшення ціни на цукор”, у Директорія, Рада Народних Міністрів Украӥнської Народної Республіки 1918-1920, т. 1, 603

47 “Ціна скарбового спирту”, у Директорія, Рада Народних Міністрів Украӥнської Народної Республіки 1918-1920, т. 1, 604; Журнал засідань Ради Народних Міністрів № 220 від 09.10.1919 р., Директорія, Рада Народних Міністрів Украӥнської Народної Республіки 1918-1920, т. 1, 542-543.

48 Журнал засідань Ради Народних Міністрів № 226 від 17.10.1919 р., Директорія, Рада Народних Міністрів Украӥнської Народної Республіки 1918-1920, т. 1, 554.

49 Закон про трудову повинність громадян Української Народної Республіки від 17 серпня 1919 р., Директорія, Рада Народних Міністрів Украӥнської Народної Республіки. Листопад 1918 - листопад 1920, т. 2, 559-562.

${ }^{50}$ Вивчення служби чужоземних військ, Директорія, Рада Народних Міністрів Української Народної Республіки 1918-1920, т. 1, 580.

51 Журнал засідань Ради Народних Міністрів № 194 від 04.09.1919 р., Директорія, Рада Народних Міністрів Украӥнської Народної Республіки 1918-1920, т. 1, 489.
} 
ISSN 2078-6077. Наукові зошити історичного факультету Львівського університету. 2018-2019. Випуск 19-20. Proceedings of History Faculty of Lviv University. 2018-2019. Issue 19-20..

вряд чи можна було ці податки зібрати. 30 жовтня 1919 р. Рада Народних Міністрів УНР виділила 10 млн. грн. на закупівлю хліба ${ }^{52}$; 16 листопада 1919 р. для опіки населення, оскільки уряд УНР полишив Поділля, Головноуповноваженим уряду УНР призначили Міністра ісповідань, професора Івана Огієнка. Під його відповідальність виділили 30 млн. грн. видатків для піклування про громадян УНР на Поділлі, забезпеку шпиталю та хворих ${ }^{53}$.

Усі грошові цінності до обстрілу Проскурова денікінцями Рада Народних Міністрів УНР евакуювала. Це було 190 тис. французьких золотих франків, 39 тис. російських золотих карбованців, близько 30 тис. срібних карбованців, приблизно 1 млрд. карбованців різною російською паперовою валютою, 6 млн. українських карбованців, 3 млн. радянських карбованців ${ }^{54}$.

Міністра праці О. Безпалка 29 грудня 1919 р. делегували з Вінниці до Варшави для висилки грошей з Румунії та Німеччини й досягнення порозуміння Армії УНР $з$ польською армією й командуванням у Кам'янці-Подільському ${ }^{55}$.

Прем'єр-міністр УНР І. Мазепа 10 лютого 1920 р. інформував з Кам'янцяПодільського голову Директорії УНР - Головного Отамана С. Петлюру про довіру населення до гривні. Висновки голови уряду УНР обумовлювались прийомом грошової одиниці на території всієї України. На зайнятій більшовиками українській території, на думку I. Мазепи, визрівала фінансова й харчова криза. Через недовіру населення до радянських грошових знаків припинився довіз до міст продуктів, непомітно зростали ціни, виникало невдоволення владою ${ }^{56}$.

Дня 6 травня 1920 р. Рада Народних Міністрів УНР змінила фіксовану ціну на цукор зі збільшенням максимальних норм до 8 i 10 тис. грн. ${ }^{57} .8$ травня 1920 p. на засіданні уряду у м. Кам'янці-Подільському розглядалось введення нових податків для українського населення. Міністр фінансів УНР запропонував ввести податки на цукор (продаж цукру в чотирьох цукроварнях по лінії Бар - Могилів у кількості 107 тис. пудів міг дати 150 млн. крб.), земельний податок, на нерухомість в містах і містечках, податок на доходи фізичних осіб (очікувані надходження - 10 млн. грн.), гербовий збір, отримати за порозуміння 3 Й. Пілсудським позику у Польщі, одноразовий податок, шкільний податок, податок на вистави, концерти, кінематограф ${ }^{58}$. Проте всі податки залишились у

52 Журнал засідань Ради Народних Міністрів № 233 від 30.10.1919 р., Директорія, Рада Народних Міністрів Української Народної Республіки 1918-1920, т. 1, 566-567.

53 Журнал засідань Ради Народних Міністрів № 237 від 16.11.1919 р., Директорія, Рада Народних Міністрів Української Народної Республіки 1918-1920, т. 1, 575.

${ }^{54}$ Ісаак Мазепа, Украӥна в огні й бурі революиії 1917-1921, 316.

55 Журнал засідань Ради Народних Міністрів № 239 від 29.12.1919 р., Директорія, Рада Народних Міністрів Украӥнської Народної Республіки 1918-1920, т. 1, 578.

${ }^{56}$ ЦДАВО, ф.3809, оп. 2, спр. 9, арк. 17.

57 Журнал засідань Ради Народних Міністрів № 8 від 06.05.1920 р., Директорія, Рада Народних Міністрів Украӥнської Народної Республіки. Листопад 1918 -листопад 1920, т. 2, 17.

58 Журнал засідань Ради Народних Міністрів № 10 від 08.05.1920 р. Директорія, Рада Народних Міністрів Украӥнської Народної Республіки. Листопад 1918 -листопад 1920, т. 2, 21. 
проєкті, оскільки Директорія УНР не контролювала більшість українських територій.

Від імени Міністра військових справ УНР В. Сальського 28 травня 1920 р. 3 Вінниці полковник Кудрявцев клопотався у Міністра фінансів УНР Барановського Х. про надання командувачу Армії УНР, генералові Михайлові Омеляновичу-Павленку скарбниці з сумою 10 млн. крб. готівки ${ }^{59}$. За контрактами військового міністерства та військового фонду до 10 травня 1920 p. безкредитово виплатили суму понад 44 млн. грн. ${ }^{60}$.

Відтак 2 червня 1920 р. Рада Народних Міністрів УНР оприлюднила декларацію про організацію ладу та повного спокою, створення ефективних органів самоврядування для проведення внутрішніх реформ, ліквідацію дорожнечі й зменшення емісій. Уряд планував залучати приватну ініціятиву до відбудови промисловости, сподіваючись на підтримку населення ${ }^{61}$. Рада Народних Міністрів УНР у Жмеринці 11 червня 1920 р. визнала за необхідне відновити діяльність Державного банку, Державної скарбниці, фінансової комісіі ${ }^{62}$. 18 червня 1920 р. на засіданні уряду УНР на ст. Проскурів вирішили поліпшити скрутний фінансовий стан держави. Засобами для цього вважали короткотермінову позичку Польщі (500 млн. 1 млрд. польських марок), довготермінову закордонну позичку (2 млрд. французьких франків чи іншої валюти) для проведення земельної реформи, короткотермінову закордонну позичку (100 млн. франків) на негайні потреби закордонних місій, надруковані у Німеччині гривні, німецькі марки з рахунку українського уряду в Райхсбанку (400 млн.), збільшення продукції експедиції державних паперів, чужоземні капітали у відродження промисловості й транспорту за участи акційної частки держави, торговельний обмін за кордоном, оподаткувати горілчану та інші державні монополії. Пропонувався продаж від імени уряду удільних, державних земель, дозвіл продажу земель містам, містечкам на поточні видатки, однак проти цього до вирішення земельної справи у повному масштабі виступив Міністр земельних справ ${ }^{63}$.

Дня 8 липня 1920 р. експедицію заготовлі державних паперів Кам'янцяПодільського після евакуації центральних установ передали під охорону й відповідальність військової влади ${ }^{64}$. Рада Народних Міністрів УНР та Міністерство фінансів Польщі 9 серпня 1920 р. підписали угоду про виготовлення за 35-40 млн. польських марок українських грошових знаків на суму 7 млрд.

\footnotetext{
${ }^{59}$ ЦДАВО України, ф. 1509, оп. 2, спр. 32, арк. 2.

${ }^{60}$ Підраховано за: ЦДАВО України, ф. 1509, оп. 1, спр. 25, арк. 5-5 зв.

${ }_{61}$ Декларація правительства Української Народної Республіки від 2 червня 1920 р., Директорія..., т. 2, 643.

62 Журнал засідань Ради Народних Міністрів № 34 від 11.06.1920р., Директорія..., т. 2, 65.

${ }^{63}$ Журнал засідань Ради Народних Міністрів № 41 від 18.06.1920 р., Директорія..., т. 2, 76-77.

64 Журнал засідань Ради Народних Міністрів № 71 від 20.07.1920 р., Директорія ..., т. 2, 127; Журнал засідань Ради Народних Міністрів № 20 від 25.05.1920 р., Директорія..., т. 2, 42.
} 
ISSN 2078-6077. Наукові зошити історичного факультету Львівського університету. 2018-2019. Випуск 19-20. Proceedings of History Faculty of Lviv University. 2018-2019. Issue 19-20..

крб. Міністерство фінансів УНР 8 жовтня 1920 р. уклало угоду з варшавською друкарнею П. Ласкауера про друк грошових знаків УНР. Загальні витрати у Варшаві по Варшавській філії експедиції, пов'язані з друком грошових знаків УНР від 1 липня до 31 грудня 1920 р., становили понад 7,7 млн. польських марок $^{65}$.

Дня 11 вересня 1920 р. Рада Народних Міністрів УНР у Тарнові вирішила асигнувати в розпорядження Міністра народного господарства УНР 40 млн. грн. (2 млн. польських марок) на закупівлю солі та нафти та 400 млн. грн. на закупівлю предметів постачання для Армії УНР ${ }^{66}$. Голова торговельноекономічної місії УНР у Варшаві Іван Фещенко-Чопівський на засіданні уряду УНР у Тарнові 23 липня 1920 р. доповів про фінансування урядом Польщі уряду УНР. Визначено місячну квоту у 50 млн. польських марок ${ }^{67}$. Через евакуацію у Варшаві припинили виготовляти гроші. Вмряджене А. Маршинським для закінчення кам'янецьке виробництво грошових знаків повернули у вагонах до Тарнова. У Тарнові, Варшаві, Станиславові на грошових знаках накладали конгрев та нумерацію ${ }^{68}$. На 31 грудня 1920 р., незважаючи на перебування уряду у Тарнові, продовжували друк гривень у Варшаві та Німеччині. У Німеччині друкували гроші Туреччини і Сіаму. Міністр фінансів УНР уклав угоду 3 німецьким акційним товариством "Ротофот" про друк для України 15 млрд. грн. за плату в 5,5 млн. німецьких марок, з умовою далі збільшити замовлення до 30 млрд. грн. ${ }^{69}$ У розпорядженні Міністерства фінансів УНР у Бреслау (Німеччина) було 164,2 млн. грн., які німецький уряд дозволив ввезти в Україну ${ }^{70}$.

Дня 16 листопада 1920 р. Рада Народних Міністрів УНР під головуванням голови А. Лівицького на ст. Гусятин вирішила перевезти Державну скарбницю, Державний банк, експедицію державних паперів на територію Польщі. При уряді УНР залишили 125 млн. крб. в карбованцях, 35 млн. грн. в гривнях та всю готівку в закордонній валюті ${ }^{71}$. Під час перебування валки Міністерства фінансів УНР на лінії Гусятин - Галац, польська влада відібрала касу Державного банку 3 готівкою на суму понад 2,3 млн. грн., 130 пачок закордонного паперу для друку грошей. Касу Державного банку скеровано до Львова в розпорядження крайової влади ${ }^{72}$. Через це Міністр фінансів УНР мусив затратити чимало зусиль до вирішення проблем.

Рада Народних Міністрів УНР на пропозицію голови Директорії УНР Головного Отамана С. Петлюри 18 листопада 1920 р. у м. Фрідріхівка визначила

${ }^{65}$ ЦДАВО України, ф. 1509, оп. 6, спр. 7, арк. 71.

${ }^{66}$ Журнал засідань Кабінету Народних Міністрів № 105 від 11.09.1920 р., Директорія..., т 2, 197.

${ }^{67}$ Журнал засідань Ради Народних Міністрів № 74 від 23.07.1920 р., Директорія..., т. 2, 132.

${ }^{68}$ ЦДАВО України, ф. 1509, оп. 1, спр. 207, арк. 121.

${ }^{69}$ Там же, оп. 6, спр. 1 , арк. 7 зв.

${ }^{70}$ ЦДАВО України, ф. 1509, оп. 6, спр.1, арк. 6 зв.

${ }^{71}$ Журнал засідань Ради Народних Міністрів № 159 від 16.11.1920 р., Директорія..., т. 2, 307.

${ }^{72}$ ЦДАВО України, ф.1509, оп.1, спр. 48, арк. 15. 
причиною невдачі Армії УНР у боротьбі з радянськими військами брак набоїв та амуніції. С. Петлюра підтримував умовний перехід уряду та війська УНР на територію Волині. На потреби армії з Сатанівської цукроварні виписали 5 тис. пудів цукру. Ціну цукру визначили для війська - 15 тис. крб. та для урядовців 10 тис. крб. за пуд. ${ }^{73} .21$ листопада 1920 р. Державний центр УНР залишив українську територію.

Рада Народних Міністрів УНР 4 січня 1921 р. видала постанову, на підставі якої у Відні створили комісію із ліквідації закордонного майна УНР у межах Австрії, Чехо-Словаччини, Італії. Виручені кошти переходили у розпорядження Міністра фінансів УНР Х. Барановського ${ }^{74}$. Відтак 3-го лютого 1921 р. відкрила своє перше засідання Рада Республіки УНР у Тарнові. Головою Ради обрали І.Фещенка-Чопівського. Депутати констатували, що у трирічній боротьбі за українську державність зросла ідея державности, на ії підтримку повстав український народ. Депутати Ради Республіки УНР констатували, що держави Европи стали рахуватись з УНР, хоча ще не визнали “нас і не йдуть до нас 3 поміччю в нашій боротьбі”75. В Універсалі Ради Республіки УНР до українського народу йшлося про швидке визволення селян-хліборобів, робітників і всіх громадян УНР. Уряд УНР й військо на чолі з Головним Отаманом УНР Петлюрою С. на чужині не втрачали надії на самостійну Українську державу. Рада Республіки УНР до всенародного обрання парламенту проголосила себе найвищою владою у всіх справах України. Висловлювалась певність, що український народ виборе собі вільне і самостійне життя в незалежній Українській Народній Республіці ${ }^{76}$. Основними завданнями Ради Народних Міністрів УНР в екзилі стало вивчення ситуації та підтримка зв'язків з українськими землями, підготова до чергової активізації повстанського уряду в Україні. Дня 25 березня 1921 р. керуючий Міністерством фінансів УНР П. Відибіда, інформуючи про фінансовий стан Державного центру УНР, повідомив про виготовлення у Польщі 3,5 із 10 млрд. українських карбованців для потреб запланованого заходу в Україні ${ }^{77}$. Фінансовий стан УНР утруднювався через витрати головних грошових запасів, вивезених Директорією УНР з Києва, урядами УНР на формування різних отаманів ${ }^{78}$. Фінансова криза в урядових структурах до середини липня 1921 р. посилилась. Державна скарбниця спорожніла, фінансові операції Міністерства фінансів УНР були невдалі. Урядовцям декілька місяців не виплачували заробітну платню. Відтак 3-го серпня 1921 р. голова Директорії

\footnotetext{
73 Журнал засідань Ради Народних Міністрів № 160 від 18.11.1920 р., Директорія..., т. 2, $308-313$.

${ }^{74}$ ЦДАВО України, ф. 1509, оп. 6, спр. 13, арк. 144.

${ }^{75}$ ЦДАВО України, ф. 1429, оп. 4, спр. 4, арк. 2.

${ }^{76}$ Там же, ф. 1065, оп. 4, спр. 23, арк. 6.

77 Ольга Малюта, “Просвіти” і Українська державність (друга половина XIX - перша половина ХХ ст.). (Київ: ВЦ “Просвіта”, 2008.), 216.

${ }^{78}$ Ісаак Мазепа, Украӥна в огні й бурі револючиї 1917-1921, 229.
} 
ISSN 2078-6077. Наукові зошити історичного факультету Львівського університету. 2018-2019. Випуск 19-20. Proceedings of History Faculty of Lviv University. 2018-2019. Issue 19-20..

УНР видав наказ розпустити Раду Республіки через фінансову неспроможність Державного Центру УНР їі утримувати ${ }^{79}$. У серпні 1921 р. в доповіді “Фінансове становище Державного центру УНР і способи до його налагодження” депутат Ради Республіки В. Приходько писав, що Державний центр УНР має залишитись центром живої державної національної ідеї ${ }^{80}$.

За період української національної революції від 1917 р. до 20 лютого 1922 р. у різних експедиціях (Київ, Одеса, Кам'янець-Подільський, Станиславів, Варшава, Берлін) надруковано грошей на суму 45,2 млрд. грн. При цьому, найбільше карбованцями - на суму 31,7 млрд. грн., гривнями - 11,5 млрд., серіями - 2 млрд., найменше - розмінними знаками на суму 46,3 млн. грн. В обіг серед населення випущено коштів на суму: понад 23 млрд. грн. Найбільше обігових коштів було в карбованцях - на суму 16,3 млрд. грн., гривнями - 5,9 млрд. грн., все інше - репрезентовано серіями та розмінними знаками. В Експедиціях Варшави та Берліна залишались 17,5 млрд. грн.: 10,9 млрд. грн.. у карбованцях та 5,5 млрд. грн. у гривнях, інше - у серіях. Чекаючи плати за друк, Німеччина затримала 6,7 млрд. грн. Урядовці УНР твердили, що Міністерство скарбу Польщі незаконно притримувало 10,9 млрд. грн. ${ }^{81}$.

Керуючий міністерством фінансів В. Приходько констатував, що на 20 лютого 1922 р. у розпорядженні уряду Української Народної Республіки було коштів на суму понад 4,6 млрд. грн., 3 них 4,5 млрд. грн. у карбованцях, 1,5 млрд. гривнями, інші кошти - розмінними знаками та серіями ${ }^{82}$. У квітні 1922 р. мали надійти кошти у сумі 8 млн. австрійських ринських (сума занижена) від уряду Австрії за знищені патрони, які належали уряду УНР ${ }^{83}$. Міністр фінансів УНР пропонував негайно погодитись навіть на занижену суму, оскільки зволікання могло призвести до втрати тих коштів.

Боротьба за українську національну державу продовжувалась всіма можливими методами в Україні та за їі межами. Найважчою була мова дипломатії, особливо у фінансово-економічних питаннях. Український народ та уряд УНР намагались утримати державність, підготувати національно свідомі кадри, налагодити й впорядкувати фінансово-економічне життя. Проте, в умовах воєнного стану, бойових дій, частих емісій, постійної зміни урядом місця дислокації, неможливо було налагодити фінансово-економічне життя. Пріоритети у міжнародній політиці впирались у наявність попередніх міжнародних зв'язків, вимушену співпраю з країнами Четвертного союзу - Німеччиною, Румунією, Болгарією, що заважало отримати підтримки Антанти. Перебуваючи у фінансово-економічній залежності від міжнародно-економічних взаємин та

\footnotetext{
${ }^{79}$ Ольга Малюта, “Просвіти” і Українська державність (друга половина XIX - перша половина XX cm.). (Київ: ВЦ “Просвіта”, 2008.), 220.

${ }^{80}$ ЦДАВО України, ф. 1509, оп. 2, спр. 24, арк. 7.

${ }^{81}$ Там же, арк. 39.

${ }^{82}$ Там же, ф. 1509, оп. 2, спр. 24, арк.34 зв.

${ }^{83}$ Там же, оп. 6, спр. 13, арк. 147.
} 
договорів, урядовці УНР зробили все можливе, щоб вистояти та вберегти українську національну державність. Співпраця з міжнародними союзниками була важчою: - i за умовами, і за результатами -ніж боротьба на фронті. Уряд УНР робив величезні зусилля, щоб зберегти державу й налагодити соціяльноекономічне життя, та не завжди міжнародна кон'юнктура була на користь Україні. Боротьба за українську державність стала боротьбою і за економічну незалежність України.

\title{
FINANCIAL AND ECONOMIC ACTIVITY OF THE SECOND UKRAINIAN PEOPLE'S REPUBLIC
}

\author{
Olga MALIUTA \\ National O.O.Bohomolets Medical University, \\ department of Ukrainian Studies, \\ prospectus Peremogi, 34, Kyiv, 03170, Ukraine \\ e-mail:maliutaov@gmail.com
}

The author in a scientific article analyzed archival materials, published sources of the activities by the Council of People's Ministers of the Ukrainian People's Republic, the Ministry of Finance of the UPR, the State Center of the Ukrainian People's Republic in the exile.

The author came to the conclusion that the statesmans of the second Ukrainian People's Republic carried out an independent financial and economic policy. International treaties concluded by Hetman Pavlo Skoropadsky, which was carried out by the Council of People's Ministers of the Ukrainian People's Republic had an impact on the internal financial and economic policy in the UPR. The Ukrainian People's Republic did not have its own mint, resorted to constant emissions with the help of Germany, Poland. Trade and economic exchange was carried out with Germany, Poland, Romania. This hindered the establishment of cooperation with the Entente.

The Directory of the UPR constantly changed its place of residence, trying to return to Kiev, conducted a number of socio-economic measures. During the existence of the Ukrainian People's Republic a number of normative legal acts were issued, which were supposed to establish a socioeconomic life, to fill the state treasury. In the Ukrainian People's Republic in the conditions of martial law, military operations, lack of budget revenues and control over a significant part of Ukrainian lands, constant emissions, the financial crisis began. The constant support of the Army of the UPR, Ukrainian Galician Army, the insurgent movement, required considerable expenditures. The own army could only support its own power and its own state. Staying on other lands led to the disarmament of military units of the Ukrainian Army.

The Directory of the UPR, under the influence of the decisions of the Paris Peace Conference and the seizure of Ukrainian lands by other states, was forced to form the State Center of the UPR in exile and for many years to leave its native land. In exile, there was a constant struggle to restore the lost Ukrainian national state.

The results of the struggle for Ukrainian statehood were determined by the independence of financial and economic life.

Keywords: Council of People's Ministers of the Ukrainian People's Republic, Directory UPR, emission, exile, international financial and economic policy, hryvnia (UAN), State Center of the Ukrainian People's Republic, Ukrainian statehood. 
ISSN 2078-6077. Наукові зошити історичного факультету Львівського університету. 2018-2019. Випуск 19-20. Proceedings of History Faculty of Lviv University. 2018-2019. Issue 19-20..

\section{REFERENCES}

Bruski Jan Jacek. Petlurowcy: Centrum Państwowe Ukraińskiej Republiki Ludowej na wychodźstwie (1919-1924). Kraków: ARCANA, 2004. (in Polish).

"Deklaratsiia pravytelstva Ukrainskoi Narodnoi Respubliky vid 2 Chervnia 1920 r.," in Directory, Council of People's Ministers of the Ukrainian People's Republic (1918-1920). K. O.Teligi Publishing house, 2006, vol. 2, 641-644. (in Ukrainian).

Dmytrienko, Maria, Uyshchenko, Victor. Money in Ukraine: Facts and Documents. Kyiv: ARS “Ukraina”, 1998. (in Ukrainian).

Hai-Nyzhnyk, Pavlo. Ukrainian Diplomacy and International Financial Policies of the Governments of the Central Rada, the Ukrainian State (Hetmanate) and the Directory of the UPR (1917-1922). Kyiv: Duliby, 2016. (in Ukrainian).

History of Money and Banking, ed. Reverchuka S. Kyiv: Atika, 2004. (in Ukrainian).

Journal of the Meetings of the Council of Pupils Ministers № 37 vid 16.12.1918, Directory, Council of People's Ministers of the Ukrainian People's Republic (1918-1920). K. O.Teligi Publishing house, 2006, vol. 1,91-94. (in Ukrainian).

Journal of the Meetings of the Council of Pupils Ministers № 40 vid 20.12.1918, Ibid, vol. 1, 102-106. (in Ukrainian).

Journal of the Meetings of the Council of Pupils Ministers № 42 vid 23.12.1918, Ibid, vol. 1, 102-106. (in Ukrainian).

Journal of the Meetings of the Council of Pupils Ministers № 45 vid 27.12.1918, Ibid, vol. 1, 120-124. (in Ukrainian).

Journal of the Meetings of the Council of Pupils Ministers № 46 vid 29.12.1918, Ibid, vol. 1, 125-131. (in Ukrainian).

Journal of the Meetings of the Council of Pupils Ministers № 65 vid 23.01.1919, Ibid, vol. 1, 205-210. (in Ukrainian).

Journal of the Meetings of the Council of Pupils Ministers № 74 vid 23.07.1920, Directory, Council of People's Ministers of the Ukrainian People's Republic (1918 - 1920), vol. 2, 132-133. (in Ukrainian).

Journal of the Meetings of the Council of Pupils Ministers № 77 vid 08.02.1919, Ibid, vol. 1, 244-247. (in Ukrainian).

Journal of the Meetings of the Council of Pupils Ministers № 142 vid 21.06.1919, Ibid, vol. 1, 373-374. (in Ukrainian).

Journal of the Meetings of the Council of Pupils Ministers № 167 vid 23.07.1919, Ibid, vol. 1, 428-430. (in Ukrainian).

Journal of the Meetings of the Council of Pupils Ministers № 194 vid 04.09.1919, Ibid, vol. 1, 488-490. (in Ukrainian).

Journal of the Meetings of the Council of Pupils Ministers № 216 vid 03.10.1919, Ibid, vol. 1, 533-535. (in Ukrainian).

Journal of the Meetings of the Council of Pupils Ministers № 220 vid 09.10.1919, Ibid, vol. 1, 540-543. (in Ukrainian).

Journal of the Meetings of the Council of Pupils Ministers № 226 vid 17.10.1919, Ibid, vol. 1, 553-555. (in Ukrainian).

Journal of the Meetings of the Council of Pupils Ministers № 232 vid 27.10.1919, Ibid, vol. 1, 564-566. (in Ukrainian).

Journal of the Meetings of the Council of Pupils Ministers № 233 vid 30.10.1919, Ibid, vol. 1, 566-567. (in Ukrainian). 
ISSN 2078-6077. Наукові зошити історичного факультету Львівського університету. 2018-2019. Випуск 19-20. Proceedings of History Faculty of Lviv University. 2018-2019. Issue 19-20.

Journal of the Meetings of the Council of Pupils Ministers № 237 vid 16.11.1919, Ibid, vol. 1, 575-576. (in Ukrainian).

Journal of the Meetings of the Council of Pupils Ministers № 8 vid 06.05.1920, Ibid, vol. 2, 1718. (in Ukrainian).

Journal of the Meetings of the Council of Pupils Ministers № 10 vid 08.05.1920 Ibid, vol. 2, 2022. (in Ukrainian).

Journal of the Meetings of the Council of Pupils Ministers № 20 vid 25.05.1920, Ibid, vol. 2, 41-43. (in Ukrainian).

Journal of the Meetings of the Council of Pupils Ministers № 34 vid 11.06.1920, Ibid, vol. 2, 64-65. (in Ukrainian).

Journal of the Meetings of the Council of Pupils Ministers № 41 vid 18.06.1920, Ibid, vol. 2, 76-77. (in Ukrainian).

Journal of the Meetings of the Council of Pupils Ministers № 71 vid 20.07.1920, Ibid, vol. 2, 126-127. (in Ukrainian).

Journal of the Meetings of the Council of Pupils Ministers №74 vid 23.07.1920, Ibid, vol. 2, 132-133. (in Ukrainian).

Journal of the Meetings of the Council of Pupils Ministers № 105 vid 11.09.1920, Ibid, vol. 2, 196-199. (in Ukrainian).

Journal of the Meetings of the Council of Pupils Ministers № 159 vid 16.11.1920, Ibid, vol. 2, 307. (in Ukrainian).

Journal of the Meetings of the Council of Pupils Ministers № 160 vid 18.11.1920, Ibid, vol. 2, 308-313. (in Ukrainian).

“Khlibna Povynnist z Urozhaiu 1919 r.”, Ukraina, 16 serpnia, 1919.

Maliuta, Olga. "Prosvita” Societes and The Ukrainian Statehood (the Second Part of the $X I X$ - the First Part of the XX Centuries). Kóiv: Publishing center "Prosvita," 2008. (in Ukrainian).

Mazepa, Isaac, Ukraine in the Fire and Storm of the Revolution of 1917-1921. Kyiv: TEMPORA, 2003. (in Ukrainian).

"Tsina Skarbovoho Spyrtu," in Directory, Council of People's Ministers of the Ukrainian People's Republic (1918-1920), vol. 1, 604. (in Ukrainian).

Verstiuk, Vladislav. "Preface", in Directory, Council of People's Ministers of the Ukrainian People's Republic (1918-1920), vol. 1, 5-22. (in Ukrainian).

"Vyvchennia Sluzhby Chuzhozemnykh Viisk," in Directory, Council of People's Ministers of the Ukrainian People's Republic (1918-1920), vol. 1, 580. (in Ukrainian).

[Without title], Central State Archives of Supreme Power and Government of Ukraine, Fund 1065, Series 4, File 23. (in Ukrainian).

[Without title], Ibid, Fund 1429, Series 4, File 4. (in Ukrainian).

[Without title], Central State Archives of Supreme Bodies of Power and Government of Ukraine, Fund 1509, Series 1, File 25. (in Ukrainian).

[Without title], Ibid, Fund 1509, Series 1, File 48. (in Ukrainian).

[Without title], Ibid, Fund 1509, Series 1, File 207. (in Ukrainian).

[Without title], Ibid, Fund 1509, Series 1, File 209. (in Ukrainian).

[Without title], Ibid, Fund 1509, Series 2, File 24. (in Ukrainian).

[Without title], Ibid, Fund 1509, Series 2, File 32. (in Ukrainian).

[Without title], Ibid, Fund 1509, Series 6, File 1. (in Ukrainian).

[Without title], Ibid, Fund 1509, Series 6, File 7. (in Ukrainian). 
ISSN 2078-6077. Наукові зошити історичного факультету Львівського університету. 2018-2019. Випуск 19-20. Proceedings of History Faculty of Lviv University. 2018-2019. Issue 19-20..

[Without title], Ibid, Fund 1509, Series 6, File 13. (in Ukrainian).

[Without title], Ibid, Fund 3809, Series 2, File 9. (in Ukrainian).

"Zakon pro Derzhavnu Ukrainsku Hroshovu Odynytsiu vid 6 Sichnia 1919 r.", in Directory, Council of People's Ministers of the Ukrainian People's Republic (1918-1920), vol. 2, 412-413. (in Ukrainian).

“Zakon pro Khlibnu Povynnist vid 9 bereznia 1919 r.," Vistnyk Derzhavnykh Zakoniv UNR, vol. 19, June 26, 1919, 26. (in Ukrainian).

"Zakon pro Trudovu Povynnist Hromadian Ukrainskoi Narodnoi Respubliky vid 17 serpnia 1919 r.," in Directory, Council of People's Ministers of the Ukrainian People's Republic (1918-1920), vol. 2, 559-562. (in Ukrainian).

"Zakon pro Vydachu Dovhostrokovykh Pozychok Tsentralnym Kooperatyvnym Ustanovam na Finansuvannia Ukrainskoi Promyslovosti vid 4 liutoho 1919 r.”, in Directory, Council of People's Ministers of the Ukrainian People's Republic (1918-1920), vol. 2, 470-471. (in Ukrainian).

"Zbilshennia Tsiny na Tsukor," in Directory, Council of People's Ministers of the Ukrainian People's Republic (1918-1920), vol. 1, 603. (in Ukrainian).

“Zemelnyi Zakon vid 8 sichnia 1919 r.", in Directory, Council of People's Ministers of the Ukrainian People's Republic (1918-1920), vol. 2, 413-417. (in Ukrainian). 